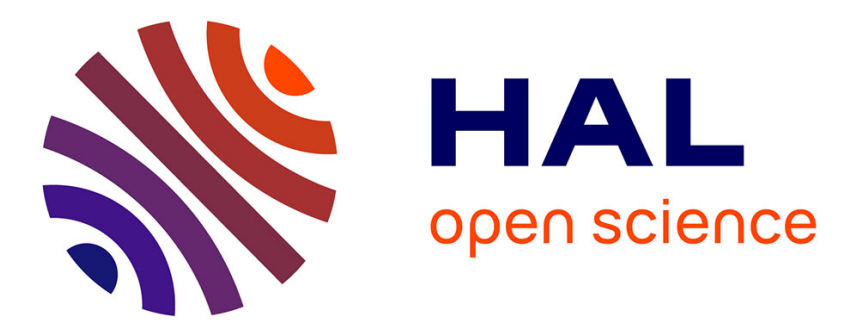

\title{
Residual alkalinity as tracer to estimate the changes induced by forage cultivation in a non-saline irrigated sodic soil
}

Laurent Barbiero, Vincent Vallès, Annick Régeard, Claude Cheverry

\section{- To cite this version:}

Laurent Barbiero, Vincent Vallès, Annick Régeard, Claude Cheverry. Residual alkalinity as tracer to estimate the changes induced by forage cultivation in a non-saline irrigated sodic soil. Agricultural Water Management, 2000, 50, pp.229-241. hal-00364725

\section{HAL Id: hal-00364725 \\ https://hal.science/hal-00364725}

Submitted on 26 Feb 2009

HAL is a multi-disciplinary open access archive for the deposit and dissemination of scientific research documents, whether they are published or not. The documents may come from teaching and research institutions in France or abroad, or from public or private research centers.
L'archive ouverte pluridisciplinaire HAL, est destinée au dépôt et à la diffusion de documents scientifiques de niveau recherche, publiés ou non, émanant des établissements d'enseignement et de recherche français ou étrangers, des laboratoires publics ou privés. 


\title{
Residual alkalinity as tracer to estimate the changes induced by forage cultivation in a non-saline irrigated sodic soil
}

\author{
Laurent BARBIERO ${ }^{1 *}$ \\ Vincent VALLES ${ }^{2}$, \\ Annick REGEARD ${ }^{3}$ \\ Claude CHEVERRY ${ }^{3}$
}

1- IRD, BP 1386 Dakar, Sénégal. (laurent.barbiero@ird.sn)

2- Université de Provence - Laboratoire de chimie et environnement (Case 29). 3, Place Victor Hugo, 13331, Marseille Cedex 3, France

3- ENSA-INRA, Unité de Sciences du Sol et d'Agronomie de Rennes /Quimper, 65 rue de St Brieuc, 35042 Rennes Cedex, France.

Correspondence

Present address: Laboratoire Mécanismes de Transfert en Géologie, UMR 5563.

39 Allées Jules Guesde, 31000 Toulouse, France

Short title: Residual alkalinity and reclamation of sodic soil

\section{Summary}

Soil alkalinisation generally constitutes a major threat to irrigated agriculture in the semiarid regions of West Africa. The improvement of sodic soils is generally difficult and expensive. However, a recent study in the Niger valley in NIGER, reveals that a natural dealkalinisation is possible under natural conditions in a semi-arid climate. Transformation of non-saline sodic soil into brown steppe soil type was recorded. On the same site, the cultivation of a Sahelian fodder grass, locally known as "Burgu" was used on the sodic soil/brown steppe soil transition zone to accelerate this natural de-alkalinisation and characterise its mechanisms. The geochemical properties of both soil types were monitored before cultivation and one year after continuous crop cultivation. After cultivation and regular irrigation, the chemical properties of the former sodic soils were close to those of the surrounding brown steppe soils, which are better suited for agriculture. This modification of the sodic soil properties can be attributed to (i) the large amount of water supplied during cultivation that induced salt leaching. This is the main phenomenon responsible for the changes observed; (ii) the root activity that modified the acid-base equilibrium and consumes alkalinity.

The Residual Alkalinity (RA) concept was used to select chemical tracers of the concentration/dilution of the soil solution. Here, sodium amount and calcite + fluorite residual alkalinity $\left(R A_{\text {calcite }+ \text { fluorite }}\right)$ were the most adequate ones. These two tracers decreased proportionally under the influence of leaching, but the exchanges between cations and protons changed the $R A_{\text {calcite }+ \text { fluorite, without modifying the sodium amount. Their combined }}$ use allowed us to separate and quantify the uptake of the plant from the leaching in the dealkalinisation process. This study highlighted that reclamation of this type of sodic soils is feasible. The use of the RA concept is advisable to design a sustainable management system for irrigated sodic or saline soils.

Key words: Sodic soils; Echinochloa stagnina; Residual Alkalinity; de-alkalinisation; Niger.

\section{Introduction}

In arid or semi-arid regions, valley bottoms are often covered by saline or sodic soils. 
Irrigation generally leads to a secondary salinisation or alkalinisation. In the west-African region, salinisation often occurs north of the Sahara Desert whereas alkalinisation appears in the Sahelian zone. The physical properties of a non-saline sodic soil reduce their agricultural potential. Sodic soil solutions poor in calcium lead to the swelling and deflocculation of clay particles when the proportion of sodium increases on the exchange complex (Shainberg \& Letey, 1984; Daoud \& Robert, 1992; Sumner, 1993). Reclamation of sodic soils is generally difficult and expensive. Several studies have recently been carried out on the effect of certain tolerant grasses in amending their soil (Abrol et al., 1988; Qadir et al., 1996a \& b). Bozza (1989) observed that the agriculture potential of a non-saline sodic soil in the Niger valley can be significantly improved with the cultivation of a Sahelian fodder grass (Echinochloa stagnina Retz. Beauv.) locally known as "Burgu" (Francois et al., 1989). The objective of this study is not to evaluate this reclamation but to understand the mechanisms associated with the apparent remediation of these soils.

Changes in the alkalinity of the soil solution may have various origins: 1 - leaching of alkalinity by the fresh irrigation during the cultivation; 2 - the plant activity that modifies the acid-base equilibrium through alkalinity production or consumption. This work is therefore carried out in three steps. In a first time, the comparison between the initial and final states of the soil (before and after cultivation) will make it possible to appreciate the global effect of the forage cultivation. In order to distinguish the effect of leaching from the effect of the plant physiology, the residual alkalinity is used as a tracer. Lastly, the ash alkalinity is calculated in order to obtain an independent second estimate of alkalinity consumption related to the plant.

\section{Material}

\section{Location}

The experiment was located at Lossa experimental station $\left(13^{\circ} 54 \mathrm{~N}-1^{\circ} 35 \mathrm{E}\right)$ INRAN (Nigerien National Institute of Agricultural Research). The 90 ha irrigated area lies at the bottom of a $10-\mathrm{km}^{2}$ catchment on the left bank of the river Niger. The climate belongs to the type III semi-arid of the African zonation (Griffiths, 1972) with a short rainy season from June to September (400 mm rainfall). During the 8-month dry season, dry winds from the Northeast raise the annual potential evapo-transpiration to $2400 \mathrm{~mm}$. The mean annual temperature is $33^{\circ} \mathrm{C}$ with maximum daily temperature up to $47^{\circ} \mathrm{C}$. The water table is located at 30 to $40 \mathrm{~m}$ below the soil surface and is not subject to evaporation. It does not contribute to changes in the soil solution.

The experimental field (1-hectare) had not been cultivated or irrigated since 1977, when the Lossa station has been developed. The soil has a sandy clay texture, and has developed on a calco-alkaline gneiss with biotite, generally observed near $1.2 \mathrm{~m}$ depth. The parent rock is part of the regional Birrimian substrata, which is locally called "Liptako bedrock". Two major differences of the soil are observed in the experimental plot; $45 \%$ of the plot is occupied by non-saline sodic soil ( $\mathrm{H}_{s}=8.5$ to 9.8 ( $\mathrm{s}=$ on saturated paste), $E C_{s}=0.22$ to $0.32 \mathrm{dS} \mathrm{m}^{-1}$, S.A.R. $=12$ to $28\left(\mathrm{mmol} \mathrm{L}^{-1}\right)^{1 / 2}$, E.S.P. $=15$ to $\left.40 \%\right)$ classified as Solonetz (FAO et al., 1994); the remaining 55\% is covered by non sodic brown steppe soil (cambic Calcisol, $p H_{s}<8.4, E C_{s}=0.07$ to $0.22 \mathrm{dS} \mathrm{m}^{-1}$, E.S.P. $=0.5$ to $2 \%$ ). The limit between the two soils is abrupt with a transition zone around $1 \mathrm{~m}$ wide, which has long been interpreted as an active alkalinisation front. However, recent studies demonstrate the active transformation of the sodic soil into a brown steppe soil (Barbiéro \& Berrier, 1994). This natural dealkalinisation will not be discussed in this paper. From a chemical point of view, calcite $\left(\mathrm{CaCO}_{3}\right)$ and fluorite $\left(\mathrm{CaF}_{2}\right)$ precipitation were identified. Those precipitations are responsible for the lateral changes observed in the soil chemistry between sodic soils and brown steppe soils (Barbiéro et al., 1995, Barbiéro \& Van Vliet Lanoë, 1998).

The infiltration rate of sodic soils is very low and its resistance to penetration 
(hardsetting) is quite high. Surface crusts develop that have the ability to impede seedling emergence. Marlet et al. (1998) has shown also that plant nutrition is perturbed on the sodic soil. The uptake of phosphorus, zinc, and more generally all the metals with no reduced forms, is blocked.

The water for irrigation comes from a temporary channel of the Niger River. Its chemical profile is a bicarbonate-calcic/sodic type at the end of the rainy season, and becomes bicarbonate-sodic during the dry season (Table I), due to the formation of calcite, during concentration by evaporation in the channel (Ribolzi et al., 1993). Such water exhibits a positive "calcite Residual Alkalinity" $\left(R A_{\text {calcite }}\right)$ and evolves in a "carbonate alkaline" way by concentration when evaporation occurs (Vallès et al., 1991), hence exhibits an alkalinising power. However, this water is fresh (the total electrolyte concentration ranges from 1.3 to $13.2 \mathrm{meq} / \mathrm{l}$ during the dry season), and can leach the soil by percolation if the balance between percolation and evaporation is favourable.

\section{Methods}

The field was pre-irrigated, tilled, harrowed, and divided into 80 plots of $20 \mathrm{~m}^{2}$ separated by small dykes. Each plot was irrigated with $50 \mathrm{~mm}$ of water twice a week during seven months and fertilised once a month during the growing season essentially with $\mathrm{KCl}$ and Urea (N $265 \mathrm{~kg} \mathrm{ha}^{-1} \mathrm{yr}^{-1}$, K $255 \mathrm{~kg} \mathrm{ha}^{-1} \mathrm{yr}^{-1}$ ). Cuttings of fodder grass were transplanted by hand in November 1991 with a $0.3-\mathrm{m}$ spacing between plants on 60 plots. The 20 remaining plots were similarly irrigated and amended without fodder grass transplantation. The semiaquatic fodder grass used, the "Burgu" Echinochloa stagnina Retz. Beauv (François et al., 1989), is common in the Sahelian rivers and used locally to feed the cattle. This plant is well suited to clayey depressions that are periodically flooded. It has a very strong fasciculated root system that is able to spread quickly into the soil profile. It is a highly productive $\mathrm{C} 4$ plant with an optimum growth temperature above $30^{\circ} \mathrm{C}$. The forage has been cut and harvested three time during the experiment on all the plot and wet and dry organic matter were recorded.

The sodic soil/brown steppe soil distribution has been delineated on the experimental field using $\mathrm{pH}$ measurements according to a regular $10-\mathrm{m}$ squared grid. Soil samples were collected with an auger at a depth of $40 \mathrm{~cm}$ before cultivation and after one year of crop growing. The $p H$ values were measured in the laboratory on saturated pastes. These data underwent an analyse of variance.

The evolution of the wetting front was followed during the cultivation using a $2 \mathrm{~cm}$ diameter drill. The drill penetrates in the wet soil and ridges in the dry soil.

Two large pits were excavated over the abrupt transition zone between the two soil types. 72 soil samples were collected along the first pit before cultivation, and 50 samples along the second one after one year of crop growing.

Extracts from the saturated pastes were analysed by ion chromatography (DIONEX) to measure the concentrations of the following elements: $\mathrm{Ca}^{++}, \mathrm{Mg}^{++}, \mathrm{Na}^{+}, \mathrm{K}^{+}, \mathrm{NH}_{4}^{+}, \mathrm{F}^{-}, \mathrm{Cl}^{-}$, $\mathrm{NO}_{2}{ }^{-}, \mathrm{NO}_{3}{ }^{-}, \mathrm{PO}_{4}{ }^{3-}, \mathrm{SO}_{4}{ }^{2-}$, oxalate, formate and acetate. A satisfactory quantification of fluoride was achieved using sodium tetraborate as eluant. The $\mathrm{pH}$ was measured first on the paste for comparison with the range of $\mathrm{pH}$ values measured in the field. It was afterwards measured on the extracts. The carbonate alkalinity (i.e., $\left.\left(\mathrm{HCO}_{3}{ }^{-}\right)+\left(\mathrm{CO}_{3}{ }^{2-}\right)\right)$, which makes up the major anionic compound, was derived from the equation of electro-neutrality of the solution because the sample volumes were too small for titration. However, an acid titration (Gran method, 1952) was carried out on three samples, giving similar results as the estimation by the ion balance. Equilibria computations were performed using the "Aqua" ion pair model (Vallès and De Cockeborne, 1992). 
According to Francois et al. (1989), the ash content varies little during the season or during the biological cycle of the plant "Burgu". The ash alkalinity of the plant material, an indirect measure of the net proton excretion by the plant, has been estimated from an average ash analysis of the plant given in Table II.

\section{Residual alkalinity and properties}

Some authors have used alkalinity as an algebraic parameter to quantify the alkalisation of the nutrient solution by plants (Vallès et al., 1993) or to calculate proton budgets or $\mathrm{H}^{+}$transfer processes involving vegetation (Van Breemen et al., 1983; Bourrié \& Lelong, 1990; Grimaldi \& Pedro, 1996). Residual alkalinity (Van Beek \& Van Breemen, 1973), which is derived from the residual carbonate concept (Eaton, 1950) and generalised by Droubi et al. (1980), has been used successfully for recent quantitative studies, and particularly for hydrograph deconvolutions (Christophersen et al., 1990; Ribolzi et al., 1996). In this study, the residual alkalinity is used as a tracer in the interpretation and the quantification of observed changes in the soil chemistry during the forage production.

The alkalinity equals the algebraic sum of the strong base cation and strong acid anion equivalents (Stumm and Morgan, 1970). In other words, it is the sum of the products of the alkaline compound concentration by the number of protons each compound can neutralise, minus the proton concentration (Bourrié, 1976):

$$
\begin{aligned}
& \text { Alk. }=\left(\mathrm{HCO}_{3}{ }^{-}\right)+\left(\mathrm{CaHCO}_{3}{ }^{+}\right)+\left(\mathrm{MgHCO}_{3}{ }^{+}\right)+\ldots \\
& \quad \ldots+\left(\mathrm{CO}_{3}{ }^{2-}\right)+\left(\mathrm{CaCO}_{3}{ }^{0}\right)+\ldots+\left(\mathrm{OH}^{-}\right)-\left(\mathrm{H}^{+}\right) \\
& \text {or } \\
& \quad \text { Alk. }=\left(\mathrm{HCO}_{3}^{-}\right)+\left(\mathrm{CO}_{3}^{--}\right)+\left(\mathrm{OH}^{-}\right)-\left(\mathrm{H}^{+}\right)
\end{aligned}
$$

where ( ) in equation 2 denote the total concentrations in equivalents. In most soils, the alkalinity equivalent is equal to the carbonate alkalinity because the proton and hydroxide ion concentrations and non-carbonate alkalinity are negligible (Voro'yeva and Zamana, 1984, Keller et al., 1987). Alkalinity is conservative inasmuch as it is affected either by the addition or loss of $\mathrm{CO}_{2}$ or by the dissolution/precipitation of a salt of strong acid or base (Stumm and Morgan, 1970). However, in arid regions, the concentration of the solutions generally leads to the formation of calcite, usually the first mineral to precipitate. Calcite residual alkalinity $\left(R A_{\text {calcite }}\right)$, is defined as the alkalinity of the solution after complete precipitation of the calcite :

$$
\begin{aligned}
& R A_{\text {calcite }}=\text { Alk. }-\left(\mathrm{Ca}^{2+}\right)-\left(\mathrm{CaHCO}_{3}^{+}\right)-\left(\mathrm{CaCO}_{3}{ }^{+}\right)-\ldots \\
& \text { Or } R A_{\text {calcite }}=\text { Alk. }-\left(\mathrm{Ca}^{2+}\right)
\end{aligned}
$$

Where $\left(\mathrm{Ca}^{2+}\right)$ in equation 4 denote the total calcium in the solution, i.e. the free calcium and the calcium ions due to mixed salts. This quantity is just as conservative during concentration as during dilution of solution affected by calcite precipitation or dissolution. This conservative aspect of the concept is shown below.

When an initial solution under-saturated with respect to calcite concentrates, as long as the equilibrium with the mineral is not reached, calcium content and alkalinity increase proportionally to the concentration of the solution. When equilibrium is reached, we have:

$(\mathrm{Alk} .)_{\mathrm{e}}=\xi(\mathrm{Alk} .)_{\mathrm{i}}$

and:

$\left(\mathrm{Ca}^{++}\right)_{\mathrm{e}}=\xi\left(\mathrm{Ca}^{++}\right)_{\mathrm{i}}$

where $\xi$ denotes the concentration ratio of the solution, ()i refers to the initial solution and ()e the solution at equilibrium.

The difference between these two equations gives (6) - (5) :

$$
\left(R A_{\text {calcite }}\right)_{\mathrm{e}}=\xi\left(R A_{\text {calcite }}\right)_{\mathrm{i}}
$$

If the concentration increases (up to $\xi$ '), calcite precipitates and a quantity "q" of equivalents of calcium and alkalinity is removed from the solution: 
$(\mathrm{Alk} .)_{\mathrm{f}}=\xi^{\prime}\left((\mathrm{Alk} .)_{\mathrm{e}}-\mathrm{q}\right)$

$\left(\mathrm{Ca}^{++}\right)_{\mathrm{f}}=\xi^{\prime}\left(\left(\mathrm{Ca}^{++}\right)_{\mathrm{e}}-\mathrm{q}\right)$

Where ()$_{\mathrm{f}}$ denotes the final concentration. The difference between these two equations gives (8) - (9) :

$\left(R A_{\text {calcite }}\right)_{\mathrm{f}}=\xi^{\prime}\left(R A_{\text {calcite }}\right)_{\mathrm{e}}$

Therefore, using (7) and (10) we can calculate:

$\left(R A_{\text {calcite }}\right)_{\mathrm{f}}=\xi . \xi^{\prime}\left(R A_{\text {calcite }}\right)_{\mathrm{i}}$

The $R A_{\text {calcite }}$ increases proportionally to the concentration ratio and therefore demonstrates the "conservative" property, even if it is obtained by the difference of two nonconservative parameters (Ribolzi et al., 1993).

This concept was extended to the successive formation of various minerals (Droubi et al., 1980) and is known as Generalised Residual Alkalinity. For example, as we will see on our site, calcite + fluorite Residual Alkalinity $\left(R A_{\text {calcite }+f l u o r i t e}\right)$ is the residual alkalinity after complete precipitation of calcite and fluorite:

$R A_{\text {calcite }+ \text { fluorite }}=$ Alk. $-\left(\mathrm{Ca}^{++}\right)+\left(\mathrm{F}^{-}\right)$

This quantity exhibits the same conservative properties in solution affected by calcite and fluorite precipitation or dissolution. After the fluorite reaches saturation (equilibrium e'), precipitation of calcite and fluorite occur together. The formation of fluorite will remove calcium and fluoride from the solution with no consumption of alkalinity. If " $\mathrm{t}$ " moles of fluorite are formed:

$\left(R A_{\text {calcite }}\right)_{\mathrm{f}^{\prime}}=\xi^{\prime \prime}\left(\left(R A_{\text {calcite }}\right)_{\mathrm{e}^{\prime}}+\mathrm{t}\right)$

$\left(\mathrm{F}^{-}\right)_{\mathrm{f}}=\xi^{\prime \prime}\left(\left(\mathrm{F}^{-}\right)_{\mathrm{e}},-\mathrm{t}\right)$

with $f^{\prime}$ refers to the final solution after fluorite precipitation (up to $\left.\xi "\right)$.

(13) and (14) can be rewritten as

$\left(R A_{\text {calcite }+ \text { fluorite }}\right)_{\mathrm{f}^{\prime}}=\xi "\left(R A_{\text {calcite }+ \text { fluorite }}\right)_{\mathrm{e}^{\prime}}$

which can be combined with (11) to give:

$\left(R A_{\text {calcite }+ \text { fluorite }}\right)_{\mathrm{f}}=\xi \xi^{\prime} \cdot \xi^{\prime \prime}\left(R A_{\text {calcite }+ \text { fluorite }}\right)_{\mathrm{i}}$

The conservative property of $R A_{\text {calcite }}$ disappears but the $R A_{\text {calcite }+ \text { fluorite }}$ remains conservative. This demonstration can also be applied for dilution processes.

Moreover, the residual alkalinity is expressed in total concentration but the soil complex is sensitive to the ratio of free cations in the soil solution. However, this formulation takes into account the ion pairs due to mixed salts, which are eliminated by difference in the expression of the residual alkalinity.

The increase in $\mathrm{CO}_{2}$ due to the roots respiration can locally induce a decrease in the $\mathrm{pH}$ value, but the alkalinity is not changed (Bourrié, 1976). If this temporary decrease in $\mathrm{pH}$ is accompanied with calcite solubilisation, the calcium and alkalinity increase in the same proportion, but the difference $\mathrm{RA}=\mathrm{Alk} .-\left(\mathrm{Ca}^{2+}\right)$ is constant.

The residual alkalinity is here used to describe and quantify the geochemical changes during cultivation for the two soil types.

\section{Results}

The $\mathrm{pH}$ values measured on saturated pastes before and after the cultivation are presented on Figure 1. A decrease in the $\mathrm{pH}$ of the field is locally observed indicating that the cultivation induced a acidification of the soil in the plot. The analyse of variance indicates that the decrease in soil $\mathrm{pH}$ value is not significative when the two soil types are analysed on the same sampling. It is however highly significative when the sodic soils are studied on a separated sampling. The decrease in $\mathrm{pH}$ value seems affect the soil which were the most alkaline before the "Burgu" cultivation. Anyway, this result shows that the acidification 
induced by the forage cultivation may be questioned, and set the necessity of a better assessment of this evolution, hence to resort to conservative parameters as the Residual Alkalinity.

The wetting front quickly reaches the horizon of bedrock weathering in the brown steppe soils. 140 days are necessary for the same result in the sodic soils (Fig. 2). The soil leaching is then possible in the two types of soil.

The range of $\mathrm{pH}$ of the samplings in the pit $(7.4-9.5)$ is similar to the range of $\mathrm{pH}$ of the whole field before and after cultivation. The chemistry of the sampling appears therefore representative of the chemistry of the field. Moreover, these data are also very similar to the values presented by several authors (unpublished) on this site on the surrounding fields, for several years.

The main geochemical processes identified at the transition from brown steppe soil to sodic soil, and responsible for the changes in the soil chemistry, are calcite and fluorite precipitations (Barbiéro \& Van Vliet Lanoë, 1998). In this case, the calcite + fluorite Residual Alkalinity $\left(R A_{\text {calcite }+ \text { fluorite }}\right)$ shows theoretically a conservative behaviour. All the soil solutions are widely under-saturated with respect to the Na-salts. Therefore, the sodium content, too, evolves conservatively, because the sodium ions are not involved in any precipitation. The effect of sodium adsorption on the exchange complex can disturb this conservative evolution and will be discussed below. The quantity of sodium and $R A_{\text {calcite+fluorite }}$ have been used to quantify the chemical evolution of the soil during cultivation.

Before cultivation, a linear relationship is observed between sodium and $R A_{\text {calcite }+ \text { fluorite }}$ (Fig. 3). After cultivation, this relationship has changed (Fig. 4). The concentrations are lower and the relationship is no longer linear. Some points slightly depart from the straight line.

\section{Discussion}

Cultivation modified the sodic soil chemistry in different ways. The sodium and $R A_{\text {calcite+fluorite }}$ concentrations are significantly lower after cultivation. This suggests a dilution process. If this dilution is only due to leaching, a constant ratio between sodium and $R A_{\text {calcite+fluorite }}$ is expected and a linear relationship between the two (Fig. 4). Parts of the measurement depart from the straight line, suggesting that the conservative behaviour of one or both of the indicators be affected. Two others processes can affect the conservative property of the indicators.

1 Drastic changes of the chemical facies of a soil solution can modify the proportions of exchangeable cations. However, these exchanges concern essentially $\mathrm{Ca}$ and $\mathrm{Na}$ because the proportion of exchangeable $\mathrm{Mg}$ does not significantly change in this environment (Barbiéro, 1995). An increase/decrease in exchangeable sodium produces an equivalent decrease/increase in exchangeable calcium, i.e., an equivalent decrease/increase in the $R A_{\text {calcite+fluorite }}$ of the soil solution. So, this process can not disturb the relationship that links sodium content and $R A_{\text {calcite }+ \text { fluorite }}$.

2 The ionic root uptake induces an exchange between cations and protons, which also disturbs the conservative property of $R A_{\text {calcite+fluorite. }}$ The change of the $p H$ in the rhizosphere, as well as in the nutrient solution, during plant growth, is well known (Smiley, 1974; Marshner and Romheld, 1983; Bernardo et al., 1984). This change depends on the nutrient source and on the plant species (Van Breemen et al., 1983) and is due in part to uptake of ammonium and potassium, and transfer of protons to the soil solution. Changes in $\mathrm{pH}$ due to $\mathrm{CO}_{2}$ consumption by the root respiration do not influence alkalinity (Bourrié, 1976) and cannot be responsible for the relation observed.

The samples that depart from the initial linear relationship were taken from a horizon, between 50 and $100 \mathrm{~cm}$ depth, which was intensely occupied by the roots and easy to delineate on the profiles. In compensation, in the superficial horizons, the root density was 
low or moderate and the points remain on the former relationship between the two indicators. Consequently, the non-linearity of the ratio between sodium and $R A_{\text {calcite }+ \text { fluorite }}$ after cultivation seems to be related to the plant contribution in the de-alkalinisation process. The plant more easily affects the geochemical facies of the soil solution, as the concentration of the soil solution is low in this non-saline sodic soil. In detail, this change expresses a decrease of alkalinity and fluoride amount without a noticeable increase of calcium amount.

Chemical balance estimate on a $20 \mathrm{~m}^{2}$-plot:

An estimate of the alkalinity uptake by the plant is:

Alk. Uptake $=\mathrm{K}+\mathrm{Na}+\mathrm{Ca}+\mathrm{Mg}-\mathrm{H}_{2} \mathrm{PO}_{4}+0.3 \mathrm{~N}$

Where the ion concentrations are expressed in equivalent and if the nitrogen source is ammonium $\left(\mathrm{NH}_{4}{ }^{+}\right)$(Vallès et al., 1993). Therefore an underestimate is:

Alk. Uptake $>\mathrm{K}+\mathrm{Na}+\mathrm{Ca}+\mathrm{Mg}-\mathrm{H}_{2} \mathrm{PO}_{4}$

$30 \mathrm{~kg}$ of dry matter of forage were produced on the $20 \mathrm{~m}^{2}$-plot during the cultivation. According to the ash analysis of the plant (Table II), the alkalinity up-taken by the plant is > 25 eq. This value must be increased with the possible acid generation through mineralisation of urea.

In the roots zone, the average decrease in the $R A_{\text {calcite }+ \text { fluorite }}$ from the initial relationship between $R A_{\text {calcite+fluorite }}$ and $\mathrm{Na}$ is $1.53 \mathrm{meq} \mathrm{l}^{-1}$. This correspond to $25.3 \mathrm{eq}$ alkalinity for a 20 $\mathrm{m}^{2}$-plot, a $0.5 \mathrm{~m}$ thick root-prospected horizon, a soil density of 1.65 , and a soil/water ratio of $1 / 1$ (the average soil/water ration of the saturated pastes).

These values ( $25 \mathrm{eq}$ and $25.3 \mathrm{eq}$ ) are very close. It is probably a coincidence, because of the uncertainty generated by this fast calculation, but we can take off that they have the same rough estimate. The non-linearity in the relation between $\mathrm{Na}$ and $R A_{\text {calcite+fluorite }}$ can therefore be attributed to the net acid contribution of the cultivation in the de-alkalinisation process.

On the other hand, an estimate of the part of leaching in the de-alkalinisation process during cultivation is given by the evolution of the upper limit of the $R A_{\text {calcite+fluorite }}$ value, which decreases from 17.1 before to $8.2 \mathrm{meq}^{-1}$ after cultivation, i.e. $8.9 \mathrm{meq}^{-1}$. This correspond to $147 \mathrm{eq}$ leached on a $20 \mathrm{~m}^{2}$-plot. This emphasises that leaching is the main phenomenon responsible for the chemical changes measured before and after cultivation (85\%)

\section{Conclusion:}

The alkalinisation process is often difficult to reverse, as an impermeable soil makes it difficult to leach sodium and alkalinity. In the "terraces" of the Niger Valley, where a natural de-alkalinisation is observed, there was an opportunity to accelerate this natural process. The non-saline sodic soils result from the precipitation of calcite and fluorite in the soil solution. The cultivation of a local semi-aquatic fodder induces chemical changes, which have been attributed to two phenomena:

1. the large amount of water supplied during cultivation produces salt leaching and it is the main phenomena, responsible for $85 \%$ of the de-alkalinisation.

2. the root activity modifies the acid-base equilibrium and consumes alkalinity. This study reveals that root activity can affect significantly such diluted soil solutions in a very short time. It is responsible for $15 \%$ of the de-alkalinisation measured in the studied plot using $\mathrm{RA}_{\text {calcite+fluorite. }}$.

When the minerals precipitating during evaporation of the soil solution are identified, it is possible to select chemical tracers using the residual alkalinity concept. In this case, the quantity of sodium and calcite + fluorite residual alkalinity $\left(\mathrm{RA}_{\text {calcite }}+\right.$ fluorite $)$ were found to be effective tracers and decreased proportionally under the influence of salt leaching. However, the exchanges between cations and protons change the $\mathrm{RA}_{\text {calcite }}+$ fluorite, without modifying the 
sodium amount. Their combined use allows separation and quantification of the action that was attributed to the plant from the leaching in the de-alkalinisation process. The use of the Residual alkalinity is advisable to design a sustainable management of irrigated sodic soils or saline soils.

\section{References}

Abrol, I.P., Yadav, J.S.P., Massoud, F.I., 1988. Salt-affected soils and their management. FAO Soils Bulletin 39, FAO, Rome.

Barbiéro, L., 1995. Les sols alcalinisés sur socle dans la vallée du fleuve Niger. Origine de l'alcalinisation et évolution des sols sous irrigation. Travaux et Documents Microfichés Orstom 138, 209 p.

Barbiéro, L., Berrier, J., 1994. Mise en évidence d'une désalcalinisation naturelle des sols en région tropicale. Transformation de sols alcalins en sols bruns subarides sur un bas fond sahélien du Niger. Comptes Rendus de l'Académie des Sciences, Paris 319, série II, 659665.

Barbiéro, L., Valles, V., Régeard, A. 1995. Contribution de la fluorine au contrôle géochimique du calcium sur un bas fond sahélien du Niger. Conséquences pour une estimation quantitative de l'évolution des sols. Comptes Rendus de l'Académie des Sciences, Paris 321, série II: 1147-1154.

Barbiéro, L., Van Vliet Lanoë, B., 1998. The alkaline soils of the Niger valley. Origins, formation and present evolution. Geoderma 84 (4), 323-343.

Beek, C.G.E. Van, Breemen, N. Van, 1973. The alkalinity of alkali soils. Journal of Soil Science 24, 129-136.

Bernardo, L.M., Clark, R.B., Maranville, J.M., 1984. Nitrate/ammonium ratio effects on mineral element uptake by sorghum. Journal of Plant Nutrition 7, 1401-1414

Bourrié, G., 1976. Relations entre le pH, l'alcalinité, le pouvoir tampon et les équilibres de $\mathrm{CO}_{2}$ dans les eaux naturelles. Science du Sol 3, 141-159.

Bourrié, G., Lelong, F., 1990. Formalization of proton balances in elementary basins based upon the alkalinity concept and graph properties. Hydrology in montainous regions I hydrological measurement : the water cycle. Proceeding of two lausanne symposia, august 1990, IAHS publication 193, 703-712.

Bozza, J., 1989. Mise en valeur et exploitation des terrasses du Niger. Rapport final, volet recherche O.N.A.H.A./F.A.C., IRAT, Montpellier.

Breemen, N. Van, Mulder, J., Driscoll, C.T., 1983. Acidification and alkalinization of soils. Plant and Soil 75, 283-308.

Christophersen, N., Neal, C., Hooper, R.P., Vogt, R.D., Andersen, S., 1990. Modelling streamwater chemistry as a mixture of soil-water end-member. A step towards second generation acidification models. Journal of Hydrology 116, 307-320.

Daoud, Y., Robert, M., 1992. Influence of particle size and clay organization on hydraulic conductivity and moisture retention of clays from saline soils. Applied Soil Science 6, 293-299.

Droubi, A.Al, Fritz, B., Gac, J.Y., Tardy, Y., 1980. Generalized residual alkalinity concept; Application to prediction of the chemical evolution of natural waters by evaporation. American Journal of Science 280, 560-572.

Eaton, F.M., 1950. Signifiance of carbonates in irrigation waters. Soil Science 69, 123-133

FAO, ISRIC, ISSS, 1994. Draft World Reference Base for Soil Ressources, Wageningen/Rome.

François, J., Rivas, A., Compere, R., 1989. Le pâturage semi-aquatique à Echinocloa stagnina (Retz.) Beauv. Etude approfondie de la plante "Bourgou" et des bourgoutières situées en 
zone lacustre du Mali. Bulletin des Recherches Agronomiques de Gembloux 24 (2), 145 189.

Gran, G., 1952. Determination of the equivalence point in potentiometric titrations. Part II. Analyst 77, 661-671.

Griffiths, J.F., 1972. Climates of Africa. World survey of climatology 10, Elsevier publish. Comp., Amsterdam.

Grimaldi, C., Pedro, G., 1996. Importance de l'hydrolyse acide dans les systèmes pédologiques des régions tropicales humides. Comptes Rendus de l'Académie des Sciences, Paris 323, série IIa:. 483-492.

Keller, C., Bourrié, G., Vedy, J.C., 1987. Formes de l'alcalinité dans les eaux gravitaires. Influence des métaux lourds contenus dans les composts, Science du Sol 25, 17-29.

Marlet, S., Barbiéro, L., Valles, V., 1998. Soil alkalinization and irrigation in the Sahelian zone of Niger II. Agronomic consequences of alkalinity and sodicity. Arid Soil Research and Rehabilitation 12, 139-158.

Marshner, H., Romheld, U., 1983. In vivo measurement of root-induced $\mathrm{pH}$ changes at the soil root interface. Effect of plant species and nitrogen source. Zeitschrift für Pflanzenphysiol. 111, 241-251

Qadir, M., Qureschi, R.H., Ahmad, N., Ilyas, M., 1996a. Salt-tolerant forage cultivation on saline sodic field for biomass production and soil reclamation. Land Degradation Development 7, 11-18.

Qadir, M., Qureschi, R.H., Ahmad, N., 1996b. Reclamation of a saline-sodic soil by gypsum and Leptochloa fusca. Geoderma 74, 207-217.

Ribolzi, O., Vallès, V., Barbiéro, L., 1993. Contrôle géochimique des eaux par la formation de calcite en milieu méditerranéen et en milieu tropical. Arguments d'équilibre et argument de bilan. Science du Sol 31 (1/2), 77-95.

Ribolzi, O., Valles, V.,Bariac, T., 1996. Comparison of hydrograph deconvolutions using residual alkalinity, chloride and oxygen 18 as hydrochemical tracers. Water Research Ressource 32 (4), 1051-1059

Shainberg, I., Letey, J., 1984. Response of soils to sodic and saline conditions. Higardia 52 (2), 1-53.

Smiley, R.W., 1974. Rhizospere pH as influenced by plants, soils and nitrogen fertilizers. Soil Science Society of America Procedings 30, 795-799.

Stumm, W., Morgan, J.J., 1970. Aquatic chemistry - An introduction emphasing chemical equilibria in natural waters. Wiley Interscience, New York.

Sumner, M.E., 1993. "Sodic soils", new perspectives. Australian Journal of Soil Research 31, 683-750

Vallès, V., Pachepsky, I., Ponizovsky, A.A., 1991. Ivariant criteria for irrigation water quality assessment in arid and semi-arid regions. In : Genesis and Control of Fertility of Salt Affected Soils : ISSS Subcommission on Salt Affected Soils Science, pp. 330-333 USSR, V.V. Dokuchaev Soil Institute, Moscow.

Vallès, V., De Cockeborne, A.M., 1992. Elaboration d'un logiciel de géochimie appliqué à l'étude de la qualité des eaux. Colloque "altération et restauration de la qualité des eaux continentales", Port Leucate, 1 et 2 Oct. 1992, 27-30.

Vallès, V., Lefevre, M., Ponizovsky, A.A., 1993. Alkalization of nutrient solutions by sorghum. Communication in Soil Science and Plant Analysis 24 (5/6), 379-388.

Vorob'yeva, A., Zamana, S.P. 1973. The nature of soil alkalinity and methods of determining it. Pochvovedeniye 3, 134-139. 

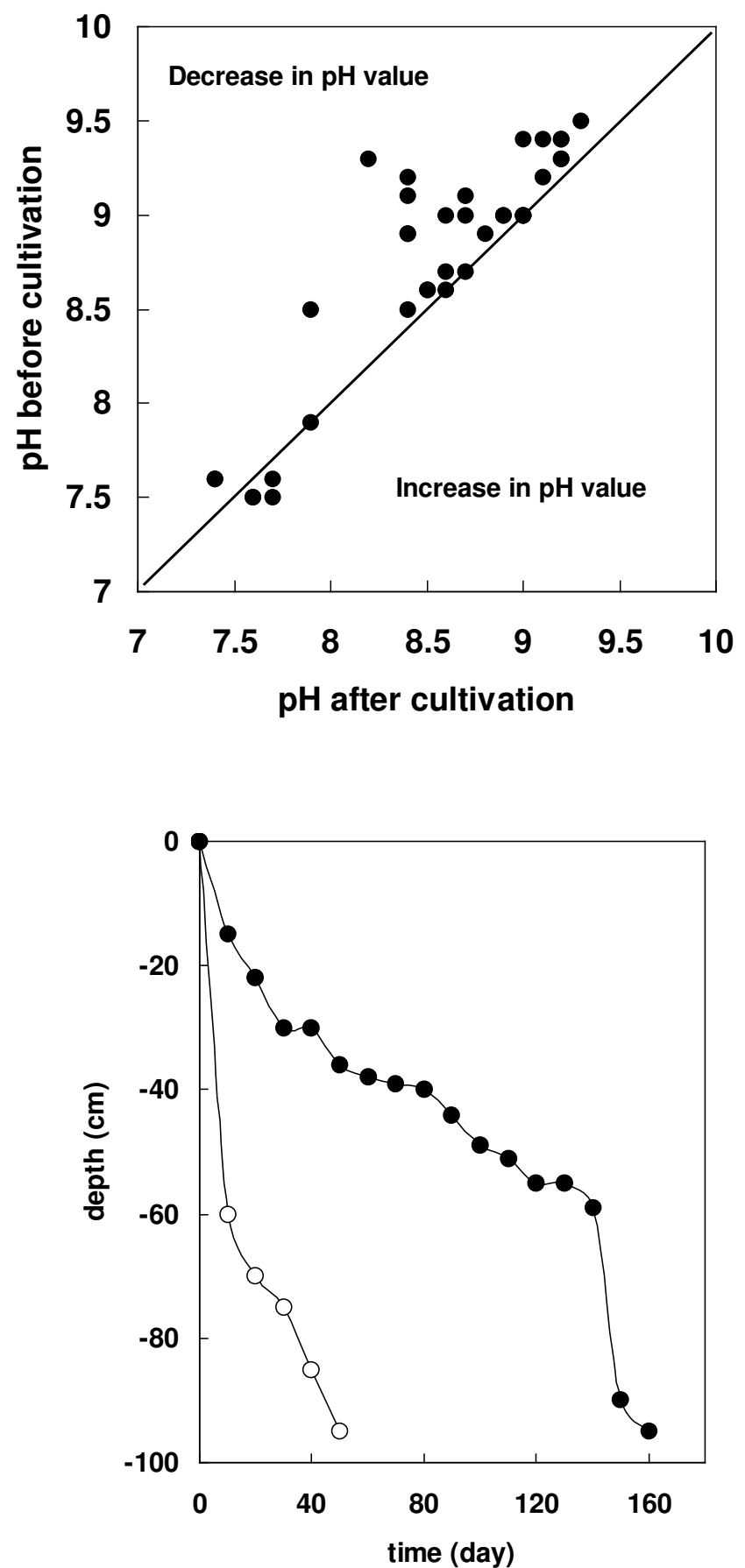

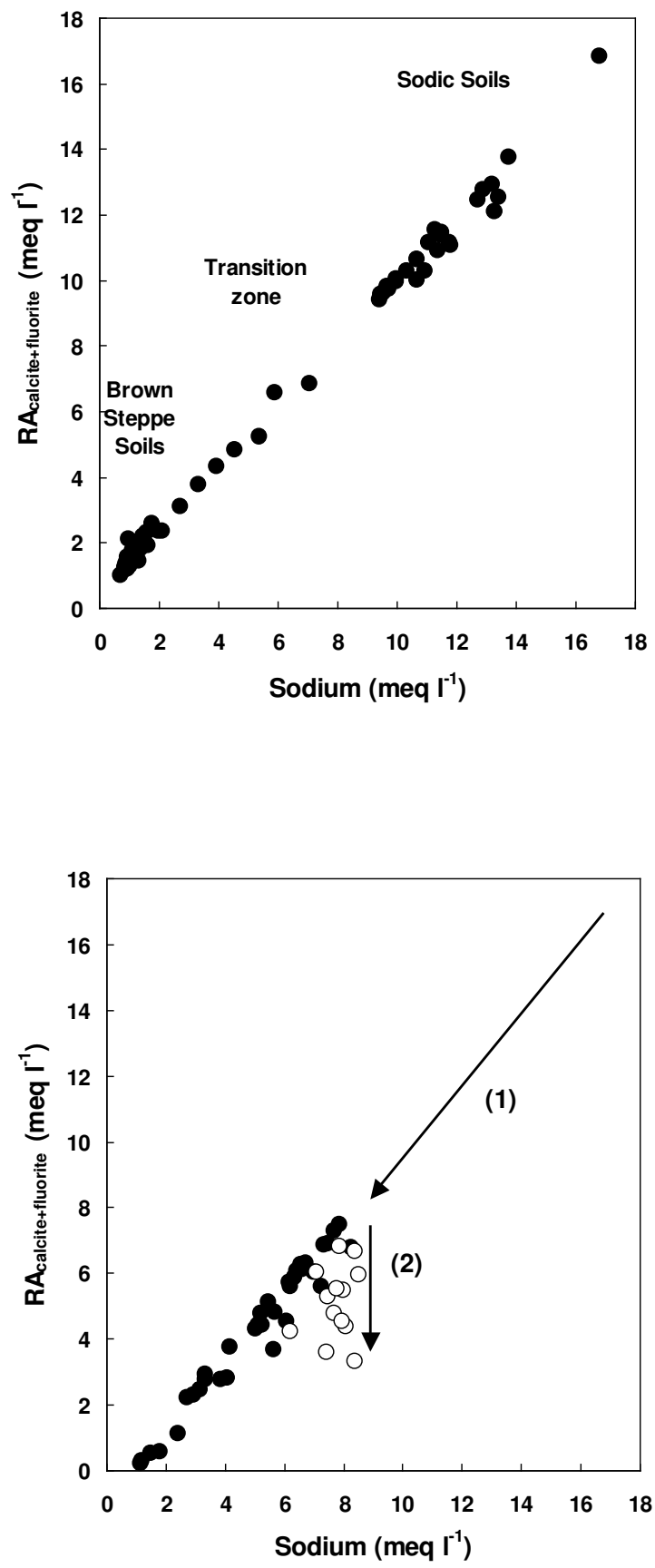
Table I: Seasonal changes in the chemistry of irrigation water.

\begin{tabular}{ccccccccc}
\hline $\begin{array}{c}\text { meq } \mathbf{I}^{-1} \\
\text { date }\end{array}$ & $\left(\mathbf{K}^{+}\right)$ & $\left(\mathbf{N a}^{+}\right)$ & $\left(\mathbf{C a}^{2+}\right)$ & $\left(\mathbf{M g}^{2+}\right)$ & $(\mathbf{C l})$ & $\left(\mathbf{S O}_{4}{ }^{2-}\right)$ & $\left(\mathbf{F}^{-}\right)$ & Alk. \\
\hline $\mathbf{1 5 - 1 2 - 9 1}$ & 0.082 & 0.287 & 0.172 & 0.090 & 0.064 & 0.008 & 0.001 & 0.559 \\
$\mathbf{1 1 - 0 5 - 9 2}$ & 0.940 & 4.620 & 0.368 & 0.132 & 1.240 & 0.013 & 0.019 & 5.878 \\
\hline
\end{tabular}

Table II : Average ash analysis of the plant Echinochloa stagnina (modified from François et al., 1989).

\begin{tabular}{cc}
\hline & g/Kg of dry matter \\
\hline $\mathbf{C a}$ & 3 \\
$\mathbf{P}$ & 1.7 \\
$\mathbf{M g}$ & 2.5 \\
$\mathbf{K}$ & 20 \\
$\mathbf{N a}$ & 0.5 \\
\hline
\end{tabular}

